\title{
Recent advances in myelodysplasia: update from 2011 ASH annual meeting
}

\author{
Delong Liu \\ From New developments in Hematology and Oncology in 2011 \\ Guangzhou, China. 25-26 December 2011
}

Significant progresses have been made in genetic research in MDS. Through RNA interference technology, knockdown of RPS14 recapitulated the pathological process of decreased erythropoiesis [1]. Transgenic expression of RPS14 in 5q- MDS cells rescued the phenotype of insufficient erythropoiesis. This strongly suggests that haploinsufficiency of RPS14 is one of the molecular mechanisms in the pathogenesis of 5q- MDS. SF3B1 is a core component of RNA splicesome and involved in the regulation of the mitochondrial pathway. In a study of 533 patients (pts) with MDS, 150 (28.1\%) was found to have SF3B1 gene mutation, which has a positive predictive value of $97.7 \%$ for RARS and correlates well with better overall survival (OS) and lower risk for AML transformation [2,3].

Hypomethylating therapy represents a significant milestone in myelodysplasia (MDS) management. TET2, IDH1/2, and DNMT3A are regulators of DNA methylation [4]. EZH2 and UTX were found to be involved in the histone H3K26 and H3K27 methylation. ASX1 was found to be deleted in $11-15 \%$ of MDS pts. In a study of 88 pts with MDS, mutations of DNMT3A, IDH1/2, and TET2 were found to be correlated with responses to azacytidine /decitabine(64\% in mutated vs $35 \%$ wild type, $\mathrm{P}=0.01$ ) [5]. microRNA-21 may also serve as a biomarker for therapy response to hypomethylating agents in MDS. In a study of 63 pts, lower level of serum miR-21 correlated with higher PFS and OS (p 0.003 and 0.001 , respectively) [6].

In terms of therapy, azacytidine $(75 \mathrm{mg} / \mathrm{m} 2 \times 5)$ was studied in combination with lenalidomide $(10 \mathrm{mg} \times 21)$ in 36 refractory pts $(\mathrm{IPSS}=>1.5)$. Overall response rate (ORR) was 71\% (CR 40, PR 31) [7]. Azacytidine (75 mg $/ \mathrm{m} 2 \times 5$ ) was also studied in combination with vorinostat (200 mg TID x 5) in 30 untreated MDS pts with poor clinical status $(\mathrm{Cr}>=1.5$, Bilirubin $>=2.0)$. ORR was $30 \%(\mathrm{CR}$

Correspondence: DELONG_LIU@NYMC.EDU

Division of Hematology /Oncology, New York Medical College \& Westchester Medical Center, Valhalla, NY 10595, USA
27\%) and OS was 7 months in these high-risk pts (expected pre-therapy OS $<60$ days) [8].

Several novel agents were also reported. Oral decitabine was reported in a phase I bioavailability trial [9]. The oral decitabine has a bioavailability of 3.9 to $14 \%$. Oral doses of 30- $240 \mathrm{mg}$ in MDS patients had similar safety profiles to that of the $20 \mathrm{mg} / \mathrm{m} 2$ IV administration. RAP-536 was found to promote erythropoiesis in a mouse model through an EPO-independent pathway [10]. IRAK1 is a serine /threonine kinase. miRNA-146a -deficient mice had IRAK1 overexpression and developed MDS-like phenotype. Phosphorylated IRAK1 was higher in MDS patients. A small molecule inhibitor of IRAK1 was studied in cell lines and in MDS sample cells. Increased apoptosis was seen in these cells. Interestingly, IRAK1 inhibitor spared the normal CD34+ cells [11].

Iron chelation therapy is increasingly used in MDS pts, especially when MDS patients are living longer with the current therapies. Retrospective analysis of iron chelation therapy in MDS pts was reported from Italy and Canada [12,13]. However, the efficacy in MDS cannot be clearly ascertained since there is no randomized prospective study specifically addressing this issue.

Published: 25 April 2012

\section{References}

1. Ebert BL, Pretz J, Bosco J, Chang CY, Tamayo P, Galili N, Raza A, Root DE, Attar E, Ellis SR, et al: Identification of RPS14 as a 5q- syndrome gene by RNA interference screen. Nature 2008, 451(7176):335-339.

2. Malcovati L, Papaemmanuil E, Hellstrom-Lindberg E, Boultwood J, Bowen D, Vyas P, Pascutto C, Porta MGD, Pellagatti A, Groves MJ, et al: Somatic Mutation of SF3B1, a Gene Encoding a Core Component of RNA Splicing Machinery, in Myelodysplasia with Ring Sideroblasts. ASH Annual Meeting Abstracts 2011, 118(21):\#3.

3. Malcovati L, Papaemmanuil E, Bowen DT, Boultwood J, Della Porta MG, Pascutto C, Travaglino E, Groves MJ, Godfrey AL, Ambaglio I, et al: Clinical significance of SF3B1 mutations in myelodysplastic syndromes and myelodysplastic/myeloproliferative neoplasms. Blood 2011, 118(24):6239-6246. 
4. Graubert T, Walter MJ: Genetics of Myelodysplastic Syndromes: New Insights. ASH Education Program Book 2011, 2011(1):543-549.

5. Traina F, Jankowska AM, Visconte V, Sugimoto $Y$, Szpurka $H$, Makishima $H$, Jerez A, O'Keefe CL, Sekeres MA, Advani AS, et al: Impact of Molecular Mutations on Treatment Response to Hypomethylating Agents in MDS ASH Annual Meeting Abstracts 2011, 118(21):\#461.

6. Min Y-H, Yoon S, Hwang DY, Kim Y, Kim Y-K, Kim Y, Cho JY, Kim JS, Kim SJ, Cheong J-W, et al: Circulating Exosomal MicroRNA-21 As a Potential Biomarker That May Predict Response to Azacitidine Treatment in Myelodysplastic Syndromes. ASH Annual Meeting Abstracts 2011, 118(21): \#3804.

7. Sekeres MA, Komrokji RS, Lancet JE, Tiu RV, Advani AS, Afable M, Englehaupt R, Juersivich J, Cuthbertson D, Paleveda J, et al: Final Results From the Phase 2 Continuation Study of the Lenalidomide and Azacitidine Combination in Patients with Higher-Risk Myelodysplastic Syndromes (MDS). ASH Annual Meeting Abstracts 2011, 118(21):\#607.

8. Garcia-Manero G, Estey EH, Jabbour E, Borthakur G, Kadia T, Naqvi K, Levine RL, Estrov Z, Quintas-Cardama A, Konopleva M, et al: Final Report of a Phase II Study of 5-Azacitidine and Vorinostat in Patients (pts) with Newly Diagnosed Myelodysplastic Syndrome (MDS) or Acute Myelogenous Leukemia (AML) Not Eligible for Clinical Trials Because Poor Performance and Presence of Other Comorbidities. ASH Annual Meeting Abstracts 2011, 118(21):\#608.

9. Mistry B, Jones MM, Kubiak P, Garcia-Manero G, Litzow MR, Mesa RA, Rifkin R, Tarassoff P, Cortes JE: A Phase 1 Study to Assess the Absolute Bioavailability and Safety of An Oral Solution of Decitabine In Subjects with Myelodysplastic Syndromes (MDS). ASH Annual Meeting Abstracts 2011, 118(21):\#3801.

10. Suragani RN, Mulivor A, Pearsall RS, Kumar R: RAP-536 Promotes Terminal Erythroid Differentiation and Reduces Anemia in Myelodysplastic Syndromes. ASH Annual Meeting Abstracts 2011, 118(21):\#610.

11. Rhyasen G, Bolanos L, Fang J, Rigolino C, Cortelezzi A, Oliva EN, Cuzzola M, Starczynowski DT: Inhibition of IRAK1 As a Novel Therapeutic Strategy in Acute Myeloid Leukemia and Myelodysplastic Syndrome. ASH Annual Meeting Abstracts 2011, 118(21):\#612.

12. Cilloni D, Messa $E$, Biale L, Bonferroni M, Salvi F, Lunghi M, Allione $B$, Ferrero D, Freilone R, Levis A, et al: High Rate of Erythroid Response During Iron Chelation Therapy in a Cohort of 105 Patients Affected by Hematologic Malignancies with Transfusional Iron Overload: An Italian Multicenter Retrospective Study. ASH Annual Meeting Abstracts 2011, 118(21):\#611.

13. Leitch HA, Chan C, Leger CS, Foltz LM, Ramadan KM, Vickars LM: Improved Survival with Iron Chelation Therapy for Lower IPSS Risk MDS Appears to Have a Stronger Association in Patients with a Non-RARS Diagnosis. ASH Annual Meeting Abstracts 2011, 118(21):\#1732.

doi:10.1186/1756-8722-5-S1-A4

Cite this article as: Liu: Recent advances in myelodysplasia: update from 2011 ASH annual meeting. Journal of Hematology \& Oncology 2012 5(Suppl 1):A4.

\section{Submit your next manuscript to BioMed Central and take full advantage of:}

- Convenient online submission

- Thorough peer review

- No space constraints or color figure charges

- Immediate publication on acceptance

- Inclusion in PubMed, CAS, Scopus and Google Scholar

- Research which is freely available for redistribution

Submit your manuscript at www.biomedcentral.com/submit
Ciomed Central 